\title{
SISTEM EKONOMI PENGRAJIN KELOM GEULIS DI gobras, KOta tasikmalaya, PROUINSI JAWA BARAT
}

\section{ECONOMIC SYSTEM OF KELOM GEULIS CRAFTSMEN IN GOBRAS, TASIKMALAYA CITY, WEST JAVA PROVINCE}

\author{
Ria Andayani Somantri \\ Balai Pelestarian Nilai Budaya Bandung \\ Jalan Cinambo No.136 Ujungberung - Bandung \\ e-mail: riaanday@ymail.com
}

\begin{abstract}
Abstrak
Penelitian Sistem Ekonomi Pengrajin Kelom Geulis di Gobras, Kota Tasikmalaya, Provinsi Jawa Barat dilaksanakan untuk menjawab masalah penelitian, yakni bagaimana pola produksi, distribusi, dan konsumsi pengrajin kelom geulis, serta aspek budaya di dalamnya. Kelom geulis diteliti karena merupakan salah satu kerajinan tradisional dari Kota Tasikmalaya yang masih bertahan dengan segala kekhasannya. Penelitian tersebut menggunakan metode penelitian deskriptif kualitatif. Adapun teknik pengumpulan data yang digunakan adalah studi pustaka, observasi, dan wawancara kepada sejumlah informan. Hasil penelitian menunjukkan bahwa pola produksi para pengrajin dapat dibedakan menjadi empat. Pertama, pengrajin fokus pada pembuatan kelom geulis bodasan; kedua, pengrajin fokus pada proses mengolah kelom geulis bodasan menjadi kelom geulis satengah jadi; ketiga, pengrajin fokus pada proses ngasakeun; dan keempat, pengrajin yang mengerjakan proses pembuatan kelom geulis dari awal sampai dengan selesai. Adapun pola distribusinya: pertama, hasil produksi dari pengrajin kelom geulis bodasan didistribusikan ke pengrajin kelom geulis setengah jadi; kedua, hasil produksi dari pengrajin kelom geulis satengah jadi didistribusikan ke pengrajin yang menangani proses finishing atau ngasakeun; ketiga, hasil produksi dari pengrajin yang mengerjakan kelom geulis secara utuh langsung dipasarkan ke konsumen. Sementara itu, pola konsumsi para pengrajin kelom geulis lebih menekankan pada pemenuhan kebutuhan primer. Bila pendapatan mereka berlebih, baru dilakukan upaya investasi.
\end{abstract}

Kata kunci: sistem ekonomi, pengrajin, kelom geulis.

\section{Abstract}

This study of Kelom Geulis Craftsmen Economic System in Gobras, Tasikmalaya, West Java Province was conducted to answer the research problem; What is the production patterns, distribution, and consumption of KelomGeulis craftsmen, as well as cultural aspects in it. Kelom geulis was studied because it is one of the craftsmen from Tasikmalaya which still surviving with all its uniqueness. The study uses descriptive qualitative research methods. Data collection techniquethat is used was literature study, observation, and interviewto a number of informants. The results showed that the pattern of production of the craftsmen can be divided into four patterns. First is artisan. Artisans focus on making Kelom Geulis bodasan; second, craftsmen focus on the process of taking Kelom Geulis Bodasan being into Kelom Geulis Satengah; Third they focus on the process of ngasakeun craftsmen; and fourth, the artist who makes the process of making Kelom Geulis from start to the completion. The distribution pattern: first, the production of craftsmen ofkelom geulis bodasan distributed to artisans kelom geulis semi-finished; secondly, the production of craftsmen kelom geulis satengah is distributed to artisans who deal with the finishing process or ngasakeun; Third, the production of the craftsmen who worked full for kelom geulis directly marketed to consumers. Meanwhile, the consumption patterns craftsmen of kelom 
geulis more emphasis on meeting the primary needs. If the excess of their income increase, the new investment will be done.

Keywords: Economic System, Craftsmen, Kelom Geulis.

\section{A. PENDAHULUAN}

Salah satu misi Kementerian Pendidikan dan Kebudayaan Indonesia adalah melestarikan dan mengembangkan kebudayaan dan kebahasaan. Misi tersebut di antaranya dijabarkan dengan cara (1) meningkatkan apresiasi pada seni dan karya budaya Indonesia sebagai bentuk kecintaan pada produk-produk dalam negeri; dan (2) melestarikan, mengembangkan, dan memanfaatkan warisan budaya sebagai gambaran jati diri bangsa serta memanfaatkan untuk kesejahteraan rakyat.

Dari penjabaran misi tersebut tampak jelas bahwa keberadaan produkproduk dalam negeri dan warisan budaya sangat penting dalam konteks pembangunan nasional. Produk dalam negeri yang sekaligus juga merupakan warisan budaya yang terdapat di Indonesia begitu banyak dan beragam. Salah satu di antaranya adalah produk kerajinan tradisional yang dimiliki oleh ratusan suku bangsa, yang tersebar di berbagai penjuru negeri.

Kelom geulis merupakan salah satu contoh produk kerajinan tradisional yang secara alami mampu menjadi salah satu identitas wilayah, yakni Kota Tasikmalaya umumnya, dan Gobras khususnya. Bila berbicara kelom geulis secara nasional, orang akan mengaitkannya dengan Kota Tasikmalaya. Sementara itu, bila berbicara kelom geulis di wilayah Tasikmalaya, orang akan menghubungkannya dengan wilayah Gobras.

Saat ini, kerajinan kelom geulis masih bertahan dengan segala kekhasannya sebagai suatu aktivitas ekonomi masyarakat Gobras di Kota Tasikmalaya. Hal itulah yang menjadi alasan dilakukan penelitian tentang Sistem Ekonomi
Pengrajin Kelom Geulis di Gobras, Kota Tasikmalaya.

Subproblematik penelitian ini adalah: (1) Bagaimanakah pola produksi, pola distribusi, dan pola konsumsi pengrajin kelom geulis di Gobras, Kota Tasikmalaya, Provinsi Jawa Barat; (2) Aspek budaya apa yang menyertai ketiga aktivitas tersebut. Adapun tujuan penelitian tersebut: (1) untuk mengetahui pola produksi, pola distribusi, dan pola konsumsi pengrajin kelom geulis di Gobras, Kota Tasikmalaya, Provinsi Jawa Barat; dan (2) untuk mengetahui aspek budaya yang menyertai ketiga aktivitas tersebut.

Ruang lingkup penelitian meliputi materi dan wilayah. Ruang lingkup materi dibatasi pada berbagai aspek yang melatarbelakangi pelaksanaan penelitian; asal-usul Gobras dan kelom geulis; pola produksi, pola distribusi, dan pola konsumsi; serta aspek-aspek budaya yang menyertai ketiga aktivitas tersebut. Adapun ruang lingkup wilayah penelitian dibatasi di wilayah Gobras, Desa Sukahurip, Kecamatan Tamansari, Kota Tasikmalaya. Gobras dipilih sebagai lokasi penelitian karena wilayah Gobras identik dengan kelom geulis.

Untuk mengarahkan penelitian tersebut diperlukan kerangka berpikir yang berisi konsep-konsep tentang kebudayaan, kerajinan tradisional, dan sistem ekonomi. Konsep-konsep tersebut diharapkan dapat menjadi pisau analisis dalam penelitian tersebut.

Konsep yang pertama adalah tentang kebudayaan. Kebudayaan menurut Miller dan Weitz (Budi Gunawan, 2012:2) memiliki beberapa perspektif: (1) Kebudayaan sebagai progres evolusioner; (2) Kebudayaan sebagai proses-proses kesejarahan; (3) Kebudayaan sebagai sistem yang terkait secara fungsional; (4) Kebudayaan sebagai konfigurasi 
kepribadian; (5) Kebudayaan sebagai sistem kognitif; (6) Kebudayaan sebagai sistem struktural; (7) Kebudayaan sebagai sistem simbolik; dan (8) Kebudayaan sebagai sistem adaptif.

Pendekatan kebudayaan yang dipandang relevan untuk penelitian tentang Sistem Ekonomi Pengrajin Kelom Geulis adalah pendekatan fungsional, yang melihat kebudayaan sebagai produk, alatalat, benda-benda atau ide dan simbol. Dalam konteks ini, kebudayaan adalah proses dinamis dan produk yang dihasilkan dari pengolahan diri manusia dan lingkungannya untuk mencapai pemenuhan hidup dan keselarasan sosial di dalam masyarakat (Ade M.K, 2013:7).

Konsep yang kedua adalah kerajinan tradisional. Kerajinan adalah barang yang dihasilkan melalui keterampilan tangan (Departemen Pendidikan Nasional, 2013: 1134). Adapun tradisional diartikan sebagai yang telah diwariskan dari generasi ke gerasi dan diterima oleh umum (Heddy Shri Ahimsa-Putra, 2006). Dengan demikian, kerajinan tradisional adalah kerajinan yang telah diwariskan dari generasi ke generasi dan diterima oleh umum.

Kerajinan tradisional biasanya memiliki kekhasan, yakni mengandung nilai-nilai estetik (Enden Irma, 2008:471). Oleh karena itu, sebagian besar bendabenda kerajinan tradisional lebih cenderung dikategorikan sebagai seni kriya. Seni kriya tiada lain adalah hasil karya seni yang bersifat terapan, artinya diciptakan dengan kesadaran dan rasa keindahan, dikerjakan dengan perorangan dengan telaten untuk dipakai atau dipergunakan dalam kehidupan sehari-hari (Th. A. Darminto, 1987:1).

Konsep yang ketiga adalah sistem ekonomi atau sistem mata pencaharian hidup. Seorang tokoh antropologi ekonomi, yakni R. Firth, mendefinisikan ekonomi sebagai seluruh perilaku manusia dalam organisasi dan pranata yang mengatur penggunaan sumber-sumber yang terbatas untuk memenuhi kebutuhan hidupnya dalam suatu masyarakat tertentu. (Koentjaraningrat, 1990:175).

Adapun pengertian sistem ekonomi adalah suatu aturan dan tata cara untuk mengatur perilaku masyarakat dalam melakukan kegiatan ekonomi untuk meraih suatu tujuan ${ }^{1}$. Sementara itu menurut M.J. Herskovits, sistem ekonomi atau mata pencaharian hidup itu tidak semata-mata ditinjau dari segi teknologinya melainkan dari pola-pola aktivitas dan interaksi yang menguasai proses produksi, distribusi, dan konsumsi (Harsojo, 1982:235).

Dalam sistem mata pencarian hidup, para ahli Antropologi juga memerhatikan sistem produksi lokalnya, cara pengolahan sumberdaya alam, cara pengumpulan modal, juga cara pengerahan dan manajemen tenaga kerja. Teknologi dalam sistem produksi, sistem distribusi pasar, dan proses konsumsinya. Kalau dirinci lebih jauh lagi termasuk di dalamnya dikaji bagaimana keterlibatan keluarga dalam mengkonsumsi suatu barang juga sistem distribusi seperti apa yang digunakan, dan siapa saja yang terlibat dalam proses produksi ${ }^{2}$. Antropologi Ekonomi berupaya untuk menjelaskan fenomena aktivitas ekonomi masyarakat tidak melulu berdasarkan teori dan konsep ekonomi modern, tetapi berkaitan erat budaya dan lingkungan fisiknya ${ }^{3}$.

\section{B. METODE PENELITIAN}

Penelitian tentang Sistem Ekonomi Pengrajin Kelom Geulis di Gobras, Kota Tasikmalaya merupakan jenis penelitian kualitatif. Zulyani Hidayah (2006) menjelaskan, pendekatan kualitatif digunakan untuk memahami persoalan sosial atau budaya manusia berdasarkan pada suatu pengembangan gambaran yang

\footnotetext{
${ }^{1} \mathrm{http}: / /$ sistempemerintahanindonesia.blogspot.com/2014/02/sistemekonomi-di-indonesia.html)

2 http://laely widjajati.blogspot.com/2012/12/antropologiekonomi.html

${ }^{3}$ http://laelywidjajati.blogspot.com/2012/12/ant ropologi-ekonomi.html
} 
kompleks dan holistis, dibangun dengan susunan kata-kata, menyajikan pandangan detail dari informan dan dilaksanakan di lingkungan alamiahnya. Studi kualitatif juga dilaksanakan dalam situasi dimana peneliti berinteraksi secara langsung dengan orang-orang yang diteliti, dalam upaya memperoleh data dari sumber pertama.

Metode penelitian yang dipandang tepat untuk penelitian tentang Sistem Ekonomi Pengrajin Kelom Geulis di Gobras adalah metode deskriptif kualitatif. Penelitian deskriptif bertujuan menggambarkan secara tepat sifat-sifat suatu gejala sosial, baik individu-individu, kelompok-kelompok, dan keadaan sosial tertentu.

Menurut Hasan dan

Koentjaraningrat (1989: 7-8), suatu pendekatan atau metode sebagai cara kerja ilmiah memerlukan alat yang merupakan perpanjangan cara dengan aspek-aspek kemudahannya, alat ini disebut teknik penelitian. Dengan demikian, dalam setiap pendekatan senantiasa ada tekniknya. Untuk mendapatkan data semaksimal mungkin dan seabsah mungkin dilakukan pendekatan kualitatif yang bersifat induktif. Dalam hal ini, kategori-kategori berasal dari informan, bukan hasil identifikasi secara a priori oleh peneliti. Teknik pengumpulan data di lapangan yang digunakan adalah pengamatan dan wawancara.

Pengamatan merupakan teknik pengumpulan data lapangan yang cukup penting. Sasaran pengamatan adalah kejadian-kejadian atau fakta-fakta sosial berkenaan dengan aktivitas ekonomi pengrajin kelom geulis di Gobras. Untuk memperbesar daya pengamatan tentang kelom geulis, digunakan alat-alat bantu, seperti alat perekam gambar (photo camera). Dengan alat tersebut, peneliti dapat memotret berbagai hal yang perlu direkam sebagai pendukung data, seperti bahan-bahan yang digunakan untuk membuat kelom geulis, proses produksi, dan hasil produksi.
Adapun wawancara dilakukan untuk memeroleh data terkait dengan materi yang ingin dijaring dalam penelitian tersebut. Sebagai panduan, digunakan instrumen penelitian berupa pedoman wawancara yang memuat sejumlah pertanyaan tentang berbagai hal di seputar kelom geulis. Pertanyaan tersebut bersifat terbuka sehingga memungkinkan peneliti menggali jawaban informan lebih jauh dan mendalam. Wawancara secara mendalam ini dilakukan kepada beberapa informan yang kriterianya sudah ditentukan sebelumnya. Kriteria informan meliputi pengetahuan dan penguasaan tentang sistem ekonomi pengrajin kelom geulis. Berdasarkan kriteria tersebut, pilihan informan jatuh pada pengrajin kelom geulis, baik pria maupun wanita yang berusia remaja juga dewasa; tokoh kelom geulis; juga tokoh masyarakat di lokasi penelitian.

Selain teknik pengumpulan data di lapangan berupa pengamatan dan wawancara, studi pustaka juga dipandang sangat perlu dilakukan. Hal itu bertujuan untuk memeroleh informasi yang berhubungan dengan materi penelitian dari berbagai literatur, seperti buku, surat kabar, majalah, jurnal, dan makalah.

\section{HASIL DAN BAHASAN}

\section{Asal-usul Gobras}

Kelom geulis sangat identik dengan Gobras. Oleh karena itu, dipandang perlu untuk mengetahui asal-usul Gobras dan kelom geulis. Berikut ini uraian asal-usul Gobras (Ria Andayani, dkk., 2001)

Gobras adalah nama yang tidak asing di wilayah Tasikmalaya. Kebesaran nama tersebut sejalan dengan popularitas satu produk kerajinan masyarakat Tasikmalaya, yakni kelom geulis. Tepatnya, Gobras merupakan daerah pengrajin kelom geulis. Meskipun nama Gobras cukup populer nama tersebut ternyata tidak tercatat secara definitif dalam administrasi pemerintahan. Selain itu, nama Gobras juga tidak tertera pada peta wilayah Kabupaten Tasikmalaya. 
Untuk mengetahui penyebab hal tersebut, ada baiknya jika terlebih dahulu menelusuri asal-usul Gobras, dari penyebutan nama Gobras hingga menghilangnya nama tersebut dalam administrasi pemerintahan.

Asal-usul Gobras erat kaitannya dengan kisah kematian seseorang yang bernama Mbah Dalem Prabu Dilaga. Melalui kisah tersebut akan diketahui latar belakang penyebutan beberapa nama dusun di seputar wilayah ini, termasuk di dalamnya Gobras. Kisah lengkap mengenai kematian Mbah Dalem Prabu Dilaga adalah sebagai berikut.

Dikisahkan ada sebuah pulau yang luasnya mencapai lebih kurang tiga hektar, terletak di tengah suatu danau. Pulau tersebut ditempati oleh seorang prabu yang bernama Mbah Dalem Prabu Dilaga beserta istrinya yang bernama Sekarningrum. Mereka tidak diketahui berasal dari mana dan tujuan menempati pulau tersebut. Konon, diperkirakan mereka membuat padepokan di tempat itu, dan menempatinya bersama para ponggawanya.

Selama sang prabu berumah tangga, tak seorang anak pun hadir dalam kehidupan mereka. Dengan alasan inilah, istri sang prabu meminta suaminya untuk menikah lagi. Dia setuju dan menikahi muridnya. Kehidupan sang prabu beserta kedua istrinya rukun dan damai selama beberapa tahun.

Pada suatu ketika, keharmonisan rumah tangga mereka terganggu oleh niat jahat istri tua sang prabu yang ingin membunuh suaminya sendiri. Rencana tersebut disampaikan kepada para ponggawa yang setia kepadanya. Para ponggawa pun melaksanakan perintah itu pada malam hari. Mereka membunuh sang prabu secara kejam hingga dia terkapar bermandikan darah. Warna merah darah yang dalam bahasa Sunda disebut beureum, menjadi dasar penyebutan nama tempat tersebut, yakni cibeureum.

Setelah membunuh sang prabu, mereka bingung mencari tempat untuk menguburkan mayatnya. Tiba-tiba mereka teringat suatu tempat berupa sebuah pulau, yang terletak di sebuah danau yang bernama Situ Gede. Lokasi danau tersebut berada di sebelah barat Tasikmalaya. Di tempat itulah mereka merencanakan untuk mengubur mayat sang prabu.

Malam itu juga mereka berkemaskemas menyiapkan segala sesuatu yang diperlukan dalam perjalanan nanti. Mayat sang prabu ditempatkan pada sebuah keranda yang dibuat dari bambu. Pada waktu dini hari, mereka sudah selesai melakukan persiapan dan segera meninggalkan tempat tersebut menuju lokasi penguburan mayat yang telah direncanakan.

Mereka pergi pada saat masih pagi buta dan gelap gulita. Dalam perjalanan, tiba-tiba mereka mulai bisa melihat berbagai hal yang berada di sekitarnya, dalam jarak pandang kurang lebih 100 meter. Ternyata pada saat itu fajar pagi telah menyingsing. Sinar fajar memberi sedikit penerangan kepada mereka. Tentu saja pandangan mereka masih remangremang, sehingga perlu mengamati sejelasjelasnya kalau memang ingin mengetahui dengan pasti. Karena kondisi inilah, tempat tersebut dinamakan Geger Noong. Maksudnya, ketika tiba di tempat tersebut mereka sudah dapat melihat keadaan sekitar meski dalam pandangan yang masih samar. Oleh karena itu, kalau menginginkan pandangan yang jelas, mereka harus mengamatinya dengan cermat.

Perjalanan menuju lokasi yang direncanakan pun dilanjutkan dengan menuruni bukit. Tiba-tiba mereka memasuki atau dalam bahasa Sunda ngagorobas ke tempat yang datar. Peristiwa mendadak menemukan tempat yang datar ini pun menjadi dasar penyebutan nama tempat tersebut yakni Dusun Gobras.

Mereka meneruskan perjalanan menuju Situ Gede. Dalam perjalanan tersebut, tiba-tiba keranda yang digunakan untuk membawa mayat sang prabu patah. 
Mereka pun berhenti dan berupaya memperbaiki keranda yang patah tersebut. Kebetulan di tempat tersebut ditemukan pohon bernama bencoy. Salah seorang di antara mereka mengambil dahannya dan dijadikan sambungan keranda yang patah. Peristiwa menyambung keranda dengan pohon bencoy ini dijadikan dasar penyebutan nama tempat tersebut, yakni Sambong Bencoy.

Keranda yang telah disambung tersebut dapat digunakan kembali. Mereka pun segera melanjutkan perjalanan yang sempat terhenti karena peristiwa tersebut. Rupanya, sambungan tadi tidak cukup kuat untuk menahan mayat sang prabu, sehingga keranda patah lagi. Tentu saja mereka harus memperbaiki kembali keranda tersebut untuk kedua kalinya.

Kebetulan salah seorang di antara mereka ada yang berilmu tinggi dan berinisiatif untuk memperbaiki keranda tersebut. Orang tersebut mengambil segenggam tanah di tempat tersebut. Dengan ilmunya yang tinggi, dia mengubah tanah menjadi sambungan keranda yang rusak. Peristiwa mengubah tanah dari bumi menjadi sambungan untuk keranda yang patah, dijadikan dasar bagi penyebutan nama tempat tersebut, yakni Sambong Mangkubumi (tempat tersebut kini menjadi tempat rekreasi berupa kolam renang).

Setelah merasa yakin keranda tersebut sudah kuat, perjalanan itu pun dilanjutkan kembali. Perjalanan panjang itu ternyata telah menguras tenaga mereka. Oleh karena itu, mereka perlu niis 'istirahat di tempat yang sejuk atau dingin' untuk melepas lelah. Kemudian, mereka pun berhenti di suatu tempat untuk beristirahat agar tenaga mereka pulih kembali. Peristiwa niis tersebut menjadi dasar penyebutan untuk tempat yang bernama Dusun Paniisan.

Mereka merasa segar dan tenaga pun pulih kembali setelah beristirahat sejenak di tempat tersebut. Perjalanan pun diteruskan lagi hingga sampai pada tujuan, yakni Situ Gede. Mereka menuju pulau yang terdapat di tengah danau tersebut, dan menguburkan mayat Mbah Dalem Prabu Dilaga.

Kisah kematian Mbah Dalem Prabu Dilaga ini merupakan satu-satunya versi yang ditemukan pada masyarakat Gobras, berkaitan dengan latar belakang penyebutan Gobras. Kebenaran kisah tersebut tentu perlu mendapat kajian yang lebih lanjut. Meskipun demikian, masyarakat setempat pernah menemukan benda-benda yang diyakini ada kaitannya dengan kisah tersebut. Ada tiga warga yang diidentifikasi bernama Engkos, Mustafa, dan Ganda pernah menemukan sejumlah perhiasan emas seperti kalung, giwang, dan cincin. Perhiasan tersebut ditemukan di lokasi yang diyakini merupakan tempat tinggal Mbah Dalem Prabu Dilaga. Penemuan tersebut terjadi pada tahun 1962, 1963, 1965, dan 1967.

Nama Gobras sendiri, pada suatu saat pernah membuat masyarakat pemilik nama tersebut malu. Mereka sering dicemoohkan dan Gobras sendiri sering dikaitkan dengan hal-hal yang janggal atau kurang baik dalam kehidupan masyarakat Tasikmalaya. Misalnya, jika terdapat orang yang dipandang tidak sopan, akan muncul idiom "seperti orang Gobras aja". Pencemaran nama Gobras ternyata berkaitan erat dengan kisah yang akan diceritakan berikut ini.

Pada masa penjajahan dulu, Dusun Gobras termasuk sarang pemberontak DI/TII. Pada suatu ketika, aparat pemerintah akan mengadakan ceramah dan pertemuan dengan masyarakat Gobras di Pondok Pesantren Cibeureum. Mereka yang datang ke tempat tersebut adalah aparat kecamatan, aparat kewedanaan, dan mantri polisi. Ceramah dari aparat pemerintah tersebut berlangsung di tempat terbuka. Ketika acara sedang berlangsung, datang serangan dari gerombolan pemberontak. Penyerangan tersebut sebenarnya mendapat perlawanan dari masyarakat di tempat itu namun tetap menelan korban. Satu di antara korban tersebut adalah camatnya sendiri. Peristiwa 
ini kemudian menjadi buah bibir dan Gobras sendiri menjadi tercemar dengan kejadian tersebut.

Gobras menjadi bahan cemoohan dan identik dengan hal-hal yang janggal atau tidak baik. Tentu saja hal itu membuat sakit hati dan malu masyarakat pemilik nama tersebut. Salah seorang warga Gobras yang bernama Aen, sangat merasakan hal itu karena dia sering berhubungan dengan masyarakat di luar Gobras. Oleh karena dia malu menyebutkan nama desanya, timbullah gagasan untuk mengganti nama Gobras.

Gagasan tersebut disampaikan kepada adiknya dan ternyata mendapat tanggapan yang positif. Selanjutnya kedua orang itu menemui Kepala Desa Gobras yang bernama Endun untuk membicarakan gagasan tersebut. Hal yang sama juga disampaikan kepada camat. Pada akhirnya semua setuju untuk mengganti nama Gobras dengan nama lain. Hanya satu nama yang tidak setuju dengan rencana penggantian nama tersebut, yakni nama sekolah. Alasannya karena nama sekolah terlanjur tercantum di pemerintah pusat.

Ketika berlangsung rapat tahunan di kecamatan, terjadilah penggantian nama Gobras secara resmi. Nama desa yang semula bernama Desa Gobras diganti menjadi Desa Sukahurip, dan Dusun Gobras menjadi Dusun Rahayu. Perubahan nama desa dan dusun tersebut ternyata hanya berlaku dan digunakan oleh masyarakatnya sendiri. Hal tersebut dapat dimaklumi karena mereka malu jika harus menyebut wilayah tempat tinggalnya di Gobras. Tidak demikian halnya dengan masyarakat di luar Gobras, mereka tetap saja menyebut Gobras untuk kawasan yang telah berganti nama menjadi Desa Sukahurip dan Dusun Rahayu.

\section{Asal-usul Kelom Geulis}

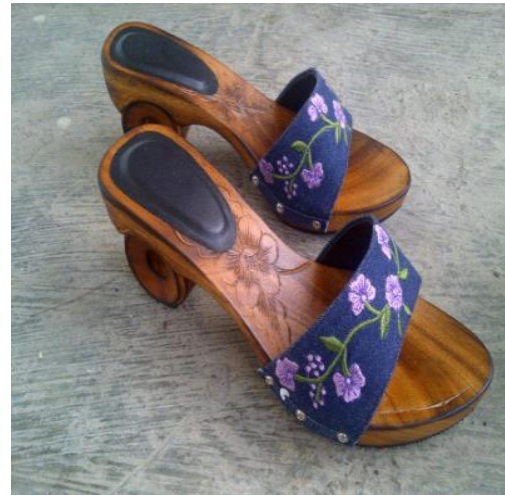

Gambar 1. Contoh Kelom Geulis

Sumber: https://www.google.com/search

Gobras dikenal sebagai sentra pengrajin kelom geulis sampai sekarang. Kelom geulis merupakan salah satu hasil kerajinan berupa alas kaki wanita yang dibuat dari kayu. Kata kelom diperkirakan diambil dari bahasa Belanda klomp (Datje Rahajoekoesoemah, 1991) yang berarti kelom. Dalam Kamus Besar Bahasa Indonesia Edisi Keempat, kelom merupakan kependekan dari kata kelompen yang berarti alas kaki yang dibuat dari kayu; bakiak; dan sandal (selop) dari kayu untuk wanita. Adapun kata geulis berasal dari bahasa Sunda yang artinya cantik. Jika diterjemahkan secara keseluruhan, kelom geulis berarti sandal kayu yang cantik. Disebut kelom geulis karena tampilan alas kaki dari kayu tersebut tampak indah dengan cat warna-warni dan ukiran motifmotif yang menarik. Konon pada masa itu, kaum wanita yang memakai alas kaki tersebut akan tampak cantik, anggun, dan mempesona

Kerajinan kelom geulis muncul pada kurun waktu 1940 s.d. 1950 di wilayah Gobras, Tasikmalaya (Ria Andayani S., dkk.). Sebelum kurun waktu tersebut, di Gobras terdapat pengrajin kelom 'sejenis alas kaki dari kayu yang diberi sabuk pengikat berwarna hitam pada bagian atasnya'; dan gamparan 'alas kaki yang dibuat dari bahan kayu dengan ciri khas ada lilingga (bagian atas gamparan yang dicapit oleh ibu jari kaki dan jari kaki yang kedua)'. Gamparan biasanya 
digunakan oleh kaum pria. Dengan demikian, kemampuan membuat sandal dari kayu sudah ada sebelum kelom geulis muncul.

Pada kurun waktu 1940 s.d. 1950, ada seorang warga Gobras bernama Pohir, ada juga yang menyebut Ohir, bekerja sebagai buruh di sebuah tempat produksi sandal di Bandung. Suatu ketika, dia dengan teman-temannya di Gobras, yakni Suryo, Ujer, dan Acep Umar ingin membuat sandal mentah dari kayu, yang di kemudian hari disebut kelom geulis.

Rencana tersebut berhasil diwujudkan oleh keempat orang itu, berupa kelom geulis mentah yang belum siap pakai karena belum ada muka atau bagian atasnya. Saat itu, mereka belum mampu membuat bagian atas kelom geulis. Mereka membawa produk tersebut ke Bandung untuk dijual dan ternyata laku. Kemudian, mereka mendapat pesanan kelom geulis mentah dari Bandung dengan model yang baru, yakni diberi hiasan ukiran.

Ide awal untuk motif ukiran pada kelom geulis terinspirasi dari lingkungan sekitar. Mereka membuat ukiran kelom geulis mentah dengan motif bunga. Hasil kreasi mereka ternyata banyak disukai konsumen. Pemasaran yang semula terbatas hanya ke Bandung, terus merambah hingga Jakarta. Seiring dengan perjalanan waktu, jumlah para pengrajin terus bertambah. Mereka pun mampu melengkapi bagian atas kelom geulis sendiri hingga siap pakai. Kelom geulis pun begitu populer bagai pelengkap busana wanita pada masa itu dan mencapai masa kejayaannya

Masa kejayaan kelom geulis berangsur-angsur hilang seiring dengan masuknya sandal buatan pabrik. Puncak kehancuran terjadi pada tahun 1970-an. Pada masa itu, hanya ada satu pengrajin yang tetap bertahan, yakni Husen. Usaha kerajinan kembali menggeliat pada tahun 1979. Saat itu ada seorang warga Gobras yang berhasil menciptakan kelom dari lembaran-lembaran kayu tripleks. Produk tersebut tidak hanya digemari konsumen dalam negeri, melainkan juga dari luar negeri, seperti Belanda. Akhirnya, kerajinan kelom geulis tetap bertahan sampai sekarang.

Selain keempat orang tadi, masih ada juga sejumlah nama yang turut berjasa dalam mengembangkan kerajinan kelom geulis pada masa itu. Mereka adalah Sahrudin, Mahmudin, Mansyur, Dahyan, Endun, dan Thio Keng Siang. Nama yang disebutkan terakhir tidak mengembangkan kelom geulis di Tasikmalaya, melainkan melebarkannya keluar wilayah Tasikmalaya.

Dikisahkan pada 1940, Thio Keng Siang pindah dari Tasikmalaya ke Jalan Pecinan Lama No. 21 Bandung dan menikah dengan wanita keturunan Cina asal Bandung. Pada 1942, dia bersama istrinya membuka usaha kecil, yakni membuat sandal kayu yang kemudian disebut kelom geulis dan menjualnya di toko miliknya, yakni Toko Kelom Geulis Keng. Pada saat itu, semua pekerjanya adalah warga keturunan Cina.

Usaha Thio Keng Siang berkembang pesat hingga hasil produksinya menembus pasar internasional. Banyak noni Belanda dan wanita keturunan Cina yang senang memakai kelom geulis sebagai pelengkap busana mereka. Salah satu motif yang cukup populer karena penggunanya adalah wanita keturunan Cina adalah kelom geulis motif barong atau naga. Konon perempuan yang belum memakai kelom geulis pada saat itu dipandang ketinggalan zaman.

Setelah berjalan 10 s.d. 15 tahun, usaha Thio Keng Siang semakin maju, bahkan rumah produksinya tak mampu memenuhi pesanan kelom geulis yang masuk ke tempat produksinya. Oleh karena itu, dia perlu menambah jumlah tenaga kerja. Untuk keperluan itu, dia mengambil tenaga kerja dari Tasikmalaya yang bagus kualitas pekerjaannya. Pengrajin yang terpilih dan diminta bekerja di tokonya adalah Rahli, Udin, dan Seng Hong.

Pada perkembangan selanjutnya, Toko Kelom Geulis Keng pindah dari 
Jalan Pecinan Lama ke Jalan Cihampelas, dan bertahan sampai dengan sekarang. Kini, pemilik Toko Kelom Geulis Keng sudah sampai pada generasi ketiga. Penerus toko kelom geulis tersebut juga membuka agennya di beberapa kota besar, yakni Medan, Surabaya, Menado, dan Pontianak.

Hubungan kerja dengan pengrajin kelom geulis di Tasikmalaya pun masih dipertahankan sampai sekarang. Pengrajin dari Tasikmalaya biasanya menjual kelom geulis setengah jadi yang berkualitas bagus. Pengrajin tersebut berasal dari Gobras.

Sejumlah pengrajin dari Gobras pernah juga mencoba membuka usaha kerajinan membuat kelom geulis di luar wilayah Tasikmalaya, namun tidak pernah berhasil. Hanya Kelom Geulis Keng yang masih bertahan di luar wilayah Tasikmalaya. Selebihnya kembali lagi melanjutkan usahanya di Gobras.

Dulu pengrajin kelom geulis hanya terkonsentrasi di Dusun Gobras (sekarang diganti Dusun Rahayu I), Desa Sukahurip, Kecamatan Tamansari, Kota Tasikmalaya. Oleh karena itu, kelom geulis sangat identik dengan Gobras. Antar-pengrajin kelom geulis memiliki ikatan kerabat satu sama lainnya karena keturunan pengrajin terdahulu membuka sendiri usaha kerajinan membuat kelom geulis. Perkembangan selanjutnya, para pekerja yang tidak memiliki ikatan kerabat pun banyak yang membuka sendiri usaha kerajinan membuat kelom geulis.

Saat ini, pengrajin kelom geulis terdapat di dua kecamatan. Pertama, Kecamatan Tamansari yang meliputi Dusun Gobras di Desa Sukahurip, Dusun Ciledug di Desa Tamanjaya, Dusun Nyemplong di Desa Setiawargi, dan Dusun Sukamaju di Desa Mulyasari. Kedua, Kecamatan Cibeureum yang meliputi Dusun Nagarakasih di Desa Kersanagara.

Dari keseluruhan mata pencaharian yang ada di Gobras, 50\% di antaranya adalah sebagai pengrajin kelom geulis.
Sementara itu di luar wilayah Gobras, jumlah terbanyak ada di wilayah Dusun Nyemplong, yang angkanya mencapai $40 \%$. Sementara itu pengrajin di wilayah lainnya, jumlahnya kurang dari itu.

Adapun Herry Miwalda juga menjelaskan tentang kelom geulis dilihat dari bentuk, ragam hias, warna, dan awal kemunculannnya. Seperti yang diketahui oleh dia, kelom geulis yang dibuat sekitar tahun lima puluhan, bentuknya tidak jauh berbeda dengan sepatu wanita bertumit tinggi, dipenuhi ukiran bunga dengan warna menyolok (kontras). Awal kemunculannya adalah sekitar tahun 1930-an, saat pertama kali di Bandung diselenggarakan jaarburs, yakni pasar tahunan. Dengan bentuk seperti itu, jelas menunjukkan disain kelom geulis mengikuti bentuk alas kaki yang umum digunakan wanita Eropa, dengan warna dan ukiran sebagai kelebihan dan kekhususan dari kelom geulis. Alas kaki tersebut mendapat pujian dari orang Belanda dengan sebutan De mooi klomp yang berarti sepatu kayu yang cantik.

\section{Pola Produksi}

3.1 Tenaga Kerja

Kelom geulis dibuat oleh orangorang yang biasa disebut pengrajin kelom geulis. Mereka menjadi pengrajin kelom geulis karena panggilan jiwa. Mereka merasa punya kewajiban meneruskan usaha pembuatan kelom geulis yang sudah diwariskan oleh leluhurnya. Apalagi usaha itu memiliki nilai ekonomis bagi mereka dan keluarganya. Pekerjaan tersebut cepat menghasilkan uang jika dibandingkan dengan menjadi petani atau pekerjaan lainnya. Selain itu, mereka juga ingin melestarikan keberadaan kelom geulis sebagai kreativitas budaya yang diwariskan oleh leluhur mereka. Mereka merasa berat kalau harus melepas usaha kelom geulis yang sudah dirintis leluhurnya.

Para pengrajin kelom geulis tersebar di Kecamatan Tamansari dan Kecamatan Cibeureum, Kota Tasikmalaya. Mereka umumnya adalah penduduk asli setempat 
yang bekerja atau mengelola usahanya dalam skala home industry 'industri rumahan', yakni jenis perusahaan kecil karena kegiatan ekonomi ini dipusatkan di rumah dan dikelola oleh keluarga. Selain menggunakan rumah sebagai tempat usaha mereka, ada juga beberapa pengrajin yang memiliki bengkel kerja secara khusus. Usaha mereka saat ini umumnya merupakan usaha turun temurun dan yang paling lama sudah sampai pada generasi ketiga.

Oleh karena skala usahanya yang bersifat industri rumahan, pembuatan kelom geulis melibatkan anggota keluarga, baik laki-laki maupun perempuan dari usia remaja hingga dewasa. Jika kekurangan tenaga kerja, mereka akan melibatkan anggota kerabat lainnya, tetangga sekitar mereka, dan bila perlu mengambil pengrajin dari luar kampung atau bahkan luar kota. Tentu saja hal itu disesuaikan dengan kualifikasi yang dibutuhkan oleh mereka.

Keahlian sebagai pengrajin kelom geulis umumnya diperoleh di dalam lingkungan keluarga secara turun temurun. Sejak kecil mereka sudah melihat secara langsung aktivitas ekonomi tersebut. Beranjak remaja, baik laki-laki maupun perempuan biasanya terlibat dalam proses produksi.

Keterlibatan mereka disesuaikan dengan jenis kelamin dan umur mereka. Artinya, ada pekerjaan yang biasa dikerjakan oleh laki-laki dan perempuan; ada juga jenis pekerjaan yang biasa dilakukan oleh remaja ( anak-anak usia setingkat SMP sampai dengan SMA) atau dewasa. Pekerjaan yang tidak memerlukan keahlian khusus biasanya diberikan kepada pengrajin perempuan, baik remaja maupun dewasa, dan pengrajin laki-laki yang masih remaja. Contohnya, perempuan dewasa dan remaja putera maupun puteri biasanya mengerjakan proses produksi pada tahapan mengampelas dan memberi cat dasar pada kelom geulis. Sementara itu, pekerjaan selebihnya dikerjakan oleh pria dewasa.
Keterampilan mereka dalam
membuat kelom geulis tidak hanya diperoleh secara informal di dalam lingkungan keluarga, tetapi juga di lingkungan masyarakat sekitar. Hal itu sangat mungkin terjadi karena tempat produksi kelom geulis tidak bersifat eksklusif. Tetangga sekitar, baik yang bukan pengrajin atau sesama pengrajin bisa saling melihat, bahkan bukan tidak mungkin saling mempelajari jika ada teknik pengerjaan yang baru atau model baru.

Jika keahlian yang diperoleh dari lingkungan keluarga dan lingkungan masyarakat dipandang belum memadai, proses pengayaan pengetahuan pun dilakukan. Salah satu di antaranya adalah dengan khusus menuntut ilmu yang berhubungan dengan kerajinan membuat kelom geulis secara formal di sekolah kejuruan atau di perguruan tinggi. Pengetahuan tersebut diharapkan dapat meningkatkan kreativitas mereka dalam membuat kelom geulis yang lebih berkualitas dan tentunya diterima oleh konsumen; serta meningkatkan kemampuan mereka dalam mengelola usaha kerajinan dengan baik.

Jumlah pengrajin yang terlibat dalam satu usaha pembuatan kelom geulis, pada umumnya terdiri atas sejumlah anggota keluarga inti ditambah dengan pekerja. Banyaknya pekerja antara 4 s.d. 6 orang. Mereka yang menjadi pekerja, bisa kerabat atau orang lain. Khusus untuk pekerja, biasanya mereka digaji berdasarkan sistem borongan atau digaji mingguan. Selain itu, bonus akan diberikan jika usaha tersebut berhasil melebihi target penjualan. Akan tetapi, pengrajin yang masih merupakan anggota keluarga inti biasanya tidak pernah dibayar. Hal itu dipandang sebagai kewajiban bagi anggota keluarga ikut terlibat membantu pekerjaan orang tuanya. Selain itu, keterlibatan tersebut dianggap penting sebagai proses pembelajaran bagi anak.

Pada umumnya, pengrajin muda kurang tertarik untuk bekerja di tempat 
usaha orang lain. Kalaupun pada akhirnya mereka tidak memiliki alternatif pekerjaan lain, dengan modal seadanya pun mereka sudah bisa membuka usaha sendiri.

Usaha para pengrajin kelom geulis berjalan sendiri-sendiri. Tidak ada satu wadah yang menghimpun dan mempersatukan keberadaan mereka. Upaya ke arah itu pernah dilakukan dahulu melalui sebuah koperasi yang bernama Koperasi Gabungan Pengrajin Kelom. Bahkan, koperasi tersebut sempat mendapat bantuan dana. Akan tetapi, koperasi tersebut tidak dapat dipertahankan lebih lama lagi karena dipandang gagal dalam pengelolaannya.

\subsection{Modal dan Bahan Baku}

Sejauh ini, modal yang digunakan untuk usaha membuat kelom geulis berasal dari kekayaan milik pribadi atau uang muka dari pemesan kelom geulis. Ketika akan meningkatkan kapasitas produksi, biasanya pengrajin menghadapi kendala keterbatasan modal. Pada saat seperti itulah, pinjaman dari lembaga keuangan biasanya sangat diperlukan. Akan tetapi, bukan perkara mudah juga untuk mendapatkan fasilitas tersebut karena banyak persyaratan yang harus dipenuhi. Meskipun demikian, banyak juga pengrajin yang dapat memanfaatkan peluang tersebut. Mereka mendapat fasilitas kredit dari lembaga keuangan, baik milik pemerintah maupun swasta.

Salah satu peruntukan modal tadi di antaranya untuk membeli bahan baku yang akan digunakan dalam proses produksi. Bahan baku tersebut meliputi kayu, beragam jenis bahan baku untuk muka atau bagian atas kelom geulis, lem, ampelas, cairan untuk menutupi pori-pori kayu, paku, dan cat.

Jenis kayu yang digunakan untuk membuat kelom geulis adalah kayu sengon, arba atau albasia, mahoni, dan kidamar. Kelebihan kayu tersebut dari kayu lainnya adalah warnanya yang putih bersih, ringan, dan kuat. Dalam jumlah yang besar, misalnya di atas 10 kubik, kayu-kayu tersebut diperoleh dari daerah Cisalopa, Cikalong, Cikatomas, dan Buni Asih. Sementara itu, dalam jumlah yang kecil, kayu tersebut bisa didapat dari penjual kayu atau bandar yang ada di sekitar tempat tinggal para pengrajin.

Kualitas kayu yang baik dan bagus adalah kayu-kayu yang berusia tua pada saat ditebang. Kayu-kayu seperti itu mudah didapat pada zaman dulu. Akan tetapi, hal itu sukar didapat saat ini. Sebagian besar jenis kayu yang digunakan saat ini adalah jenis mahoni, dan ditebang pada saat usia yang belum cukup tua. Oleh karena itu, agak sulit untuk mendapatkan kualitas hasil produksi kerajinan kelom geulis sebaik dahulu.

Bahan baku untuk muka atau bagian atas kelom geulis sangat beragam dan mengikuti perkembangan zaman. Beberapa di antaranya yang sering digunakan adalah dari bahan kulit, imitasi, kain, rajutan, bordiran, batik, atau disesuaikan dengan keinginan pemesan. Bahan baku tersebut bisa dibeli di toko-toko yang ada di Kota Tasikmalaya. Akan tetapi, ada kalanya mereka juga harus mendesain atau memesan secara khusus untuk pesananpesanan istimewa dari para konsumennya.

Adapun bahan-bahan lainnya seperti lem, ampelas, cat, dan cairan untuk menutupi poro-pori kayu atau bahan sending bisa dibeli di toko-toko yang ada di sekitar tempat tinggal para pengrajin.

\subsection{Proses Produksi}

Pada dasarnya para pengrajin memahami proses pembuatan kelom geulis atau proses produksi dari awal sampai dengan selesai. Tahapan yang harus dilakukan terhadap kayu yang akan dibuat kelom geulis dari awal sampai dengan selesai adalah diukur, dipotong, dipola, diputer, disugu atau diserut, dipola pinggulan, dihak, diles, dipo, dihampelas, divariasi, disending, diangin-angin, dihampelas, dan disemprot.

Proses tersebut cukup panjang sehingga memerlukan waktu yang cukup lama. Jika pengrajin mengerjakan 
semuanya, akan terlalu lama bagi mereka untuk mendapatkan penghasilan dari usaha tersebut. Oleh karena itu, pengrajin umumnya tidak melakukan semua tahapan produksi sebagai bentuk usahanya. Akan tetapi, mereka hanya fokus pada pembuatan bagian-bagian tertentu sebagai bentuk usahanya. Jika dikelompokkan, setidaknya terdapat 4 bentuk usaha pengrajin kelom geulis yang sangat terkait dengan pola produksi mereka.

\section{a. Pengrajin yang Membuat Kelom Geulis Bodasan}

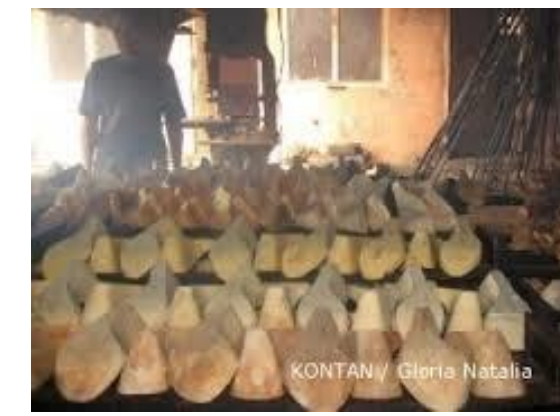

Gambar 2. Contoh Kelom Geulis Bodasan Sumber: https://www.google.com/search

Membuat kelom geulis bodasan merupakan tahap awal dalam proses pembuatan kelom geulis. Pengrajin yang terlibat pada tahapan ini adalah pengrajin laki-laki yang sudah dewasa. Peralatan produksi yang digunakan untuk membuat kelom geulis di antaranya gergaji baik yang manual maupun semi manual, pisau, golok, sugu raut, dan sugu jegong. Adapun bahan baku yang harus disiapkan adalah kayu.

Ada beberapa jenis pekerjaan yang dilakukan oleh pengrajin terhadap kayu sebagai bahan baku utama untuk membuat kelom geulis, yakni:

- Diukur, yakni mengukur kayu dengan panjang $50 \mathrm{~cm}$ untuk ukuran kelom geulis dewasa, dan $30 \mathrm{~cm}$ untuk ukuran kelom geulis anak-anak. Adapun ketebalan kayunya sekitar $10 \mathrm{~cm}$;

- Dipotong, yakni memotong kayu yang telah diukur tadi;

- Dipola, yakni memberi pola gigir 'pola samping' pada potongan kayu tadi, kemudian dibelah sesuai dengan pola gigir tersebut. Selanjutnya potongan kayu tersebut diberi pola tampah 'pola untuk bagian atas';

- Diputer, yakni menggergaji potongan kayu tersebut menurut pola tampah dan menyisakan bagian ujungnya; kemudian memotong kayu tersebut untuk memisahkan pasangannya dan bagian ujungnya;

- Disugu atau diserut, yakni menghaluskan bagian yang telah diberi pola tampah 'pola bagian permukaan atas' dengan dua cara yakni disosok 'menyerut dengan alat sugu sosok' untuk menghasilkan permukaan yang rata; dan dijegong 'menyerut dengan alat sugu jegong' untuk menghasilkan permukaan yang ada lekukannya;

- Dipola pinggulan, kemudian diserut dengan dua cara yakni diliken untuk menghasilkan bagian belakang berlekuk dan diratakan;

- Dihak, yakni menyambungkan bagian atas dan hak kelom geulis. Proses tersebut dikerjakan untuk membentuk bagian bawah kelom geulis. Model hak pun bervariasi, ada yang biasa ada juga yang dilubangi;

- Diles, yakni diberi lem kayu, terutama pada bagian belakang agar tidak mudah retak;

- Dipoe, yakni menjemur kelom geulis selama dua hari agar kering atau untuk menghilangkan kadar air dalam kayu. Jika cuaca mendung, kelom geulis tersebut dipanaskan dalam oven agar kering. Oven itu dibuat dari kayu, kecuali untuk bagian alas dan daun pintunya dibuat dari seng. Oven diletakkan di atas dua buah kompor. Kelom geulis yang berada dalam oven yang tertutup rapat dipanaskan selama kurang lebih 15 jam. Jika dibandingkan, pengeringan dengan sinar matahari akan lebih baik daripada dipanaskan di dalam oven.

Hasil produksi pada tahapan ini adalah kelom geulis yang disebut kelom geulis bodasan. Ada kelom geulis yang rata atau datar, ada juga kelom geulis yang berlubang atau dilubangi. Kelom 
geulis tersebut masih harus diproses melalui tahapan berikutnya. Meskipun demikian, kelom geulis bodasan sudah memiliki nilai ekonomi karena sudah bisa dijual ke pengrajin lainnya.

\section{b. Pengrajin yang Membuat Kelom Geulis} Satengah Jadi

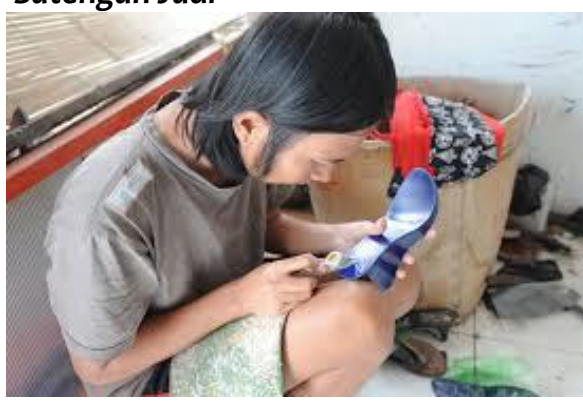

Gambar 3. Seorang pengrajin sedang membuat kelom geulis setengah jadi.

Sumber: https://www.google.com/search

Pengrajin yang membeli kelom geulis bodasan adalah pengrajin yang akan membuat kelom geulis satengah jadi. Tahapan ini merupakan kelanjutan dari tahapan membuat kelom geulis bodasan, yang melibatkan pengrajin wanita dan pria, baik remaja maupun dewasa. Tentu saja, mereka tidak terlibat dalam semua pekerjaan. Dalam hal ini ada pembagian tugas bagi mereka. Umumnya, pengrajin perempuan yang masih remaja dan sudah dewasa, serta pengrajin laki-laki yang masih remaja mendapat porsi pekerjaan yang tidak berat dan memerlukan keahlian khusus.

Peralatan produksi yang digunakan di antaranya adalah gerinda, kompresor, pisau ukir, alat semprot cat, dan ampelas. Adapun yang bahan baku pada tahapan ini adalah kelom geulis bodasan. Ada beberapa jenis pekerjaan yang dilakukan pengrajin terhadap kelom geulis bodasan, yakni:

- Dihampelas, yakni menghaluskan seluruh permukaan kelom geulis bodasan menggunakan gerinda atau ampelas. Pekerjaan tersebut biasanya ditangani oleh pengrajin pria.

- Divariasi, yakni memberi variasi pada kelom geulis bodasan, di antaranya dengan teknik ukir, teknik air brush kombinasi teknik ukir dan air brush teknik titik, teknik membatik, dan teknik dibakar. Pekerjaan tersebut biasanya ditangani oleh pengrajin pria dewasa, karena memerlukan keahlian khusus;

- Disending, yakni memberi cairan khusus pada seluruh permukaan kelom geulis bodasan untuk menutup pori-pori kayu. Pekerjaan tersebut biasanya ditangani oleh pengrajin yang masih remaja dan pengrajin wanita.

- Diangin-angin, yakni menempatkan kelom geulis bodasan tadi di tempat terbuka agar kering terkena hembusan angin.

- Dihampelas, yakni menghaluskan kelom geulis bodasan untuk yang terakhir kalinya menggunakan ampelas;

- Disemprot, yakni mengecat kelom geulis agar mengkilat atau warna dop dengan bantuan alat semprot; dan

- Disol, yakni menempelkan sol pada bagian bawah kelom geulis satengah jadi.

Hasil produksi pengrajin pada tahapan ini adalah kelom geulis satengah jadi dengan beragam motif yang dihasilkan dari beragam teknik membuat motif. Ada motif flora, fauna, abstrak, atau disesuaikan dengan keinginan pemesan sebelumnya. Satu motif yang paling klasik dan masih ada sampai sekarang adalah motif bunga. Hasil produksi tersebut biasanya dijual kepada pengrajin yang akan memberi muka atau bagian atas pada kelom geulis; bisa juga dikirim langsung kepada pemesan selain pengrajin yang berasal dari luar kota.

\section{c. Pengrajin yang Ngasakeun}




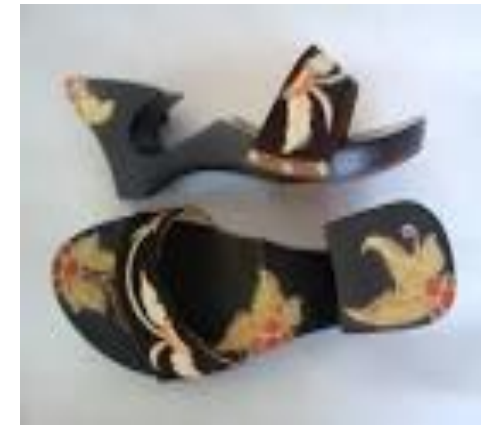

Gambar 4. Kelom geulis hasil proses ngasakeun.

Gambar: https://www.google.com/search

Pengrajin yang ngasakeun adalah pengrajin yang menggarap tahap akhir dari pembuatan kelom geulis. Pengrajin yang melakukan pekerjaan tersebut bisa laki-laki atau perempuan. Mereka bekerja menggunakan peralatan produksi, seperti palu, mesin jahit, gunting, dan pisau untuk memotong karet. Adapun bahan baku yang diperlukan oleh para pengrajin adalah kelom geulis satengah jadi dan muka atau bagian atas kelom geulis. Khusus untuk muka kelom geulis, pengrajin bisa membuat sendiri atau membeli yang sudah jadi. Di Gobras, memang ada yang secara khusus membuat dan menjual muka untuk kelom geulis dari beragam jenis bahan, yakni kulit, imitasi, kain, rajut, bordiran, dan lain-lain.

Pekerjaan yang dilakukan oleh pengrajin pada tahapan ini adalah memberi muka atau bagian atas pada kelom geulis satengah jadi dan memasang label jika ada. Kelom geulis satengah jadi yang telah diproses sampai tahap ini meningkat menjadi kelom geulis yang sudah siap untuk digunakan. Ada kalanya, proses ngasakeun tidak dilakukan oleh pengrajin di Gobras, melainkan oleh pembeli yang berasal dari luar wilayah Gobras.

5.

Hasil produksi pengrajin pada tahap ini tentu saja kelom geulis yang sudah siap untuk digunakan.

\section{d. Pengrajin yang Membuat Kelom Geulis Secara Utuh}

Hanya sedikit pengrajin yang membuat kelom geulis secara utuh, dari awal sampai dengan selesai. Kemungkinan yang pertama dia memiliki modal yang cukup besar dan tenaga kerja yang cukup banyak sehingga memilih alternatif yang satu ini. Kemungkinan kedua, pengrajin memiliki modal dan tenaga kerja yang sangat terbatas sehingga jumlah produksinya sedikit. Oleh karena itu, pengrajin tersebut lebih memilih menyelesaikan sendiri pembuatan kelom geulis hingga siap pakai.

\section{Pola Distribusi}

Kelom geulis didistribusikan dengan beberapa cara:

- Pertama, hasil produksi dari pengrajin kelom geulis bodasan didistribusikan ke pengrajin kelom geulis setengah jadi;

- Kedua, hasil produksi dari pengrajin kelom geulis satengah jadi didistribusikan ke pengrajin yang menangani proses finishing atau ngasakeun;

- Ketiga, hasil produksi dari pengrajin yang mengerjakan kelom geulis secara utuh langsung dipasarkan ke konsumen, baik berdasarkan pesanan langsung, menjual di toko milik sendiri, atau menjual secara online di internet. Mereka bisa menjual secara eceran atau kodian.

Konsumen kelom geulis di antaranya berasal dari berbagai kota besar di Indonesia. Adapun pasar internasional yang terjangkau oleh mereka di antaranya negara-negara di Asia Tenggara, Korea, Afrika, Jepang, Panama, Timur Tengah, dan sebagian wilayah Eropa.

\section{Pola Konsumsi}

Hasil penjualan kelom geulis pada umumnya adalah pendapatan berupa uang. Prioritas penggunaan uang tersebut adalah untuk memenuhi kebutuhan hidup keluarga sehari-hari atau kebutuhan primer, seperti sandang, pangan, papan, pendidikan, dan modal untuk produksi. Jika kebutuhan primer sudah terpenuhi dan masih ada 
lebihnya, baru upaya invenstasi untuk jangka panjang dilakukan oleh mereka, seperti dalam bentuk kepemilikan rumah yang bagus, sawah atau tanah, dan kendaraan pribadi.

\section{Aspek Budaya dalam Sisten Ekonomi Pengrajin Kelom Geulis}

Kebudayaan adalah proses dinamis dan produk yang dihasilkan dari pengolahan diri manusia dan lingkungannya untuk mencapai pemenuhan hidup dan keselarasan sosial di dalam masyarakat. Budaya merupakan kristalisasi dari proses adaptasi manusia dalam memenuhi kebutuhan hidupnya. Mencermati aspek budaya yang menyertai aktivitas sistem ekonomi pengrajin kelom geulis di Tasikmalaya memang cukup menarik.

Aspek budaya yang paling tampak adalah dalam pola produksi kelom geulis yang tidak semata-mata urusan teknis menjadikan bongkahan kayu menjadi sepasang alas kaki. Akan tetapi, pengetahuan mereka dalam membuat alas kaki, seperti caranya, bentuk disain, dan motif gambar yang dipilih merupakan ranah budaya para pengrajin kelom geulis. Ada pewarisan pengetahuan keterampilan membuat kelom geulis yang berlangsung di dalam lingkungan keluarga dari generasi ke generasi. Ada proses pengadopsian teknik membatik pada motif kelom geulis. Ada proses akulturasi dalam motif gambar pada kelom geulis, yakni motif naga atau barong karena pada masanya kelom geulis banyak digunakan oleh perempuan keturunan Cina. Akulturasi juga tampak dalam penamaan kelom geulis, yang berasal dari bahasa Sunda, yakni kata geulis yang berarti cantik; dan kata kelom yang merupakan serapan dari bahasa Belanda, yakni klompen yang berarti sandal dari kayu; dan lain-lain.

Satu lagi yang cukup menarik adalah aspek budaya yang tampak pada pola konsumsi para pengrajin kelom geulis. Nilai prestis atau kebanggaan atas kesuksesan dalam menjalankan usaha mereka sebagai pengrajin kelom geulis juga terlihat. Hal itu tampak dari kepemilikan rumah bagus berikut isinya, bahkan bisa lebih dari satu; kepemilikan mobil mewah, yang juga bisa lebih dari satu.

\section{PENUTUP}

Kerajinan merupakan kekayaan budaya masyarakat Tasikmalaya, dan salah satu produknya adalah kelom geulis dari Gobras. Dilihat dari namanya, lokalitas tampak jelas pada penggunaan kata geulis yang berasal dari bahasa Sunda.

Kelom geulis dapat dikategorikan sebagai kerajinan tradisional karena sudah ditekuni secara turun-temurun. Itu artinya sudah terjadi proses pewarisan keahlian membuat kelom geulis dari generasi ke generasi. Pengrajin saat ini sudah sampai pada generasi yang ketiga. Kekhasan kelom geulis terletak pada bagian bawah kelom geulis yang dibuat dari kayu. Hal itu merupakan kreativitas budaya mereka dalam memanfaatkan sumber daya alam di sekitarnya untuk memenuhi kebutuhan hidup mereka, yakni untuk alas kaki.

Kreativitas tersebut terus berkembang dan dikembangkan dari waktu ke waktu hingga menghasilkan beragam bentuk, model, dan motif. Adapun untuk bagian atas kelom geulis dibuat dari beragam bahan, seperti kulit, imitasi, kain, dan bentuk lainnya sesuai dengan perkembangan zaman. Kelom geulis umumnya difungsikan sebagai alas kaki layaknya sandal untuk wanita; dan ada juga yang difungsikan sebagai sepatu tali.

Dalam menjalankan aktivitas ekonomi tersebut, tercermin pula aspekaspek budaya di dalamnya. Roda produksi yang dilakukan oleh para pengrajin begitu memerhatikan nilai-nilai keindahan, ketekunan, ketelitian, lokalitas agar menghasilkan tampilan fisik kelom geulis yang khas, indah, dan nyaman dipakai.

Aktivitas para pengrajin dalam membuat kelom geulis juga memperlihatkan nilai kebersamaan dan gotong royong dalam keluarga agar dapat 
memproduksi kelom geulis di lingkungan rumahnya masing-masing secara efisien dan efektif. Keterikatan satu sama lainnya juga tercermin dalam sistem ekonomi mereka yang saling berhubungan. Pengrajin kelom geulis bodasan berhubungan dengan pengrajin kelom geulis satengah jadi; pengrajin kelom geulis satengah jadi berhubungan dengan pengrajin yang ngasakeun. Semua itu seakan-akan merupakan satu ikatan yang tidak terpisahkan dalam mewujudkan kreasi mereka, yakni kelom geulis.

\section{DAFTAR SUMBER}

\section{Makalah, Laporan Penelitian, dan Jurnal}

Ahimsa-Putra, H.S. "Tradisi/Adat Istiadat: Pemahaman dan Penerapannya". Makalah dalam kegiatan Pembekalan di Direktorat Tradisi, Jakarta 2006.

Bustami, Abd. Latif. "Teknik Inventarisasi Kepercayaan Komunitas Adat”, Makalah dalam Bimbingan Teknis Komunitas Adat, Sumedang, 16-18 November 2011.

Gunawan, Budi. "Konsep dan Metode Kajian Kebudayaan", Makalah dalam Bimbingan Teknis Penelitian. Bandung, 27 Februari 2012.

Hidayah, Zulyani. "Metodologi Penelitian Kepercayaan Masyarakat", Makalah dalam Penataran Tenaga Teknis Pamong, Jakarta, 2006.

"Fenomena Perubahan Nilai dalam Upacara Adat di Indonesia", Makalah dalam Bimbingan Teknis Inventarisasi Komunitas Adat, Cisarua-Bogor, 14-16 Juni 2013.

Wiwalda, Herry. "Payung Tasik dan Kelom Geulis di dalam Kehidupan Masyarakat Tasikmalaya dari Masa ke Masa".

Makmur K., Ade, dkk. 2013.

Kajian Nilai Budaya Lokal Masyarakat Jatigede. Laporan Penelitian. Bandung: BPNB Bandung.

Somantri, Ria Andayani,Yudi Putu Satriadi, Agus Heryana, Nina Merlina, Adeng, Enden Irma Rachmawati, Suwardi Alamsyah Priarana. 2001.

Nilai-nilai Budaya yang Berkembang pada Masyarakat di Kabupaten
Tasikmalaya. Laporan Penelitian. Bandung: Pusat Penelitian Kemasyarakatan dan Kebudayaan, Lembaga Penelitian UNPAD.

Irma, Enden. "Kerajinan Tradisional dari Bahan Logam di Kecamatan Rajapolah Kabupaten Tasikmalaya" dalam Jurnal Penelitian Volume 40. Nomor 1. April 2008. Hlm. 471.

\section{Buku}

Darminto, Th.A. 1987.

Aspek Seni Kriya dalam Arus Modernisasi. Jakarta: Departemen Pendidikan dan Kebudayaan.

Departemen Pendidikan Nasional. 2013.

Kamus Besar Bahasa Indonesia. Jakarta: PT Gramedia Pustaka Umum.

Harsojo.1982.

Pengantar Antropologi. Bandung: Penerbit Binacipta.

Koentjaraningrta. 1990.

Sejarah Teori Antropologi II. Jakarta: Penerbit Universitas Indonesia (UI Press).

Rahajoekoesoemah, Datje. 1991.

Kamus Belanda-Indonesia Jilid 1, Jakarta: 1991.

\section{Internet}

Arisanti, Desiska dkk. "Teori-teori Emile Durkheim", diunduh dari http://www.slideshare.net/oellfauswa/teor i-emile-durkheim, tanggal 15 Juli 2014, Pukul 20.00 WIB.

N.N. "Antropologi ekonomi", diakses dari http://laelywidjajati.blogspot.com/2012/1 2/antropologi-ekonomi.html, tanggal 25 Juli 2015, Pukul 13.00 WIB.

Dynash, Juan. "Sitem ekonomi Indonesia", diunduh dari http://sistempemerintahanindonesia.blogspot.com/2014/02/sistemekonomi-di-indonesia.html, Tanggal 31 Agustus 2015, Pukul 14. 45 WIB. 